\title{
Letter in response to "Vascular endothelial cadherin shedding is more severe in sepsis patients with severe acute kidney injury"
}

\author{
Richard W Pierce(B)
}

\section{This comment refers to the article available at: https://doi.org/10.1186/s13054-019-2315-y.}

\section{Dear Editor,}

I read with great interest $\mathrm{Yu}$ et al.'s study on vascular endothelial cadherin (VE-cadherin) in patients with sepsis and kidney injury [1]. The endothelium has long been implicated in the pathogenesis of critical illness. Despite our enthusiasm, insights linking changes occurring within endothelial cells (ECs) to clinically observed pathophysiology are few and far between. As noted, VE-cadherin is a complex molecule, a component of adherens junctions (AJs) as well as a multifaceted signaling molecule. Yu et al.'s study highlights the clinical utility of VE-cadherin as a potential biomarker of EC injury but falls short of providing mechanistic insight to EC dysfunction in critical illness.

VE-cadherin is specific to ECs and may be released as soluble-(s)VE-cadherin through several mechanisms, each with distinct pathophysiologic implications. Intact VE-cadherin may detach from the membrane of dead or dying ECs. More commonly, VE-cadherin may be actively cleaved, forming sVE-cadherin species with distinct molecular weights and, presumably, functions [2]. Different cleavage sites for VE-cadherin are identified for specific matrix metalloproteinases; however, no sVE-cadherin species has a known physiologic role [3]. Similarly, soluble adhesion molecules (i.e., sICAM) are commonly studied as markers of EC "dysfunction" but have no understood biologic functions, complicating interpretation of elevated levels. Finally, VE-cadherin may be shed in EC-derived microvesicles, which serve as signaling platforms to other ECs or immune cells [4]. Unfortunately, the study by $\mathrm{Yu}$ and colleagues does not demarcate the type of VE-cadherin detected in patient's blood, complicating interpretation of its mechanistic implications.

Furthermore, the authors expressed surprise over the lack of correlation with sVE-cadherin and total fluid balance. This finding could be explained by the differential junctional specificity across vascular segments. AJs are characteristic of the venular segment. Venular leak is physiologic, allowing for localized inflammatory response and rarely results in clinical consequences. The capillary vascular segment is characterized by tight junctions (TJs). Once established, $\mathrm{TJ}$ integrity does not depend on AJs. Capillary leak is pathologic and, due to exponentially greater cumulative surface area, is clinically impactful. TJ breakdown can be assessed in critically ill patients [5], and preserved $\mathrm{TJ}$ function may explain the lack of correlation between sVE-cadherin and fluid balance.

Investigations of the vascular response to critical illness remain paramount to our understanding of complex diseases like shock, sepsis, and multiple organ dysfunction. Broadly characterizing vascular components will likely not result in meaningful mechanistic insights. Special attention to the vascular segment and the meaningfulness of surveyed byproducts of EC dysfunction will better advance our field.

Sincerely,

Richard Pierce, MD, MS

Yale University, Department of Pediatrics, Section of Critical Care

Vascular Biology and Therapeutics Program

\section{Acknowledgements}

Not applicable 
Funding

None

Availability of data and materials

Not applicable

Author's contributions

Richard Pierce conceptualized and drafted the letter. The author read and approved the final manuscript.

Ethics approval and consent to participate

Not applicable

\section{Consent for publication}

Yes

Competing interests

The author declares that he has no competing interests.

\section{Publisher's Note}

Springer Nature remains neutral with regard to jurisdictional claims in published maps and institutional affiliations.

Received: 5 March 2019 Accepted: 25 April 2019

Published online: 14 May 2019

\section{References}

1. Yu W-K, McNeil JB, Wickersham NE, Shaver CM, Bastarache JA, Ware LB. Vascular endothelial cadherin shedding is more severe in sepsis patients with severe acute kidney injury. Crit Care. 2019;23:18.

2. Flemming S, Burkard N, Renschler M, Vielmuth F, Meir M, Schick MA, et al. Soluble VE-cadherin is involved in endothelial barrier breakdown in systemic inflammation and sepsis. Cardiovasc Res. 2015;107:32-44.

3. Su W, Kowalczyk AP. The VE-cadherin cytoplasmic domain undergoes proteolytic processing during endocytosis. Mol Biol Cell. 2017;28:76-84.

4. Hromada C, Mühleder S, Grillari J, Redl H, Holnthoner W. Endothelial extracellular vesicles_-promises and challenges. Front Physiol. 2017:8:1-11.

5. Vermette D, Hu P, Canarie MF, Funaro M, Glover J, Pierce RW. Tight junction structure, function, and assessment in the critically ill: a systematic review. Intensive Care Med Exp. 2018;6:37.

- fast, convenient online submission

- thorough peer review by experienced researchers in your field

- rapid publication on acceptance

- support for research data, including large and complex data types

- gold Open Access which fosters wider collaboration and increased citations

- maximum visibility for your research: over $100 \mathrm{M}$ website views per year

At BMC, research is always in progress. 